
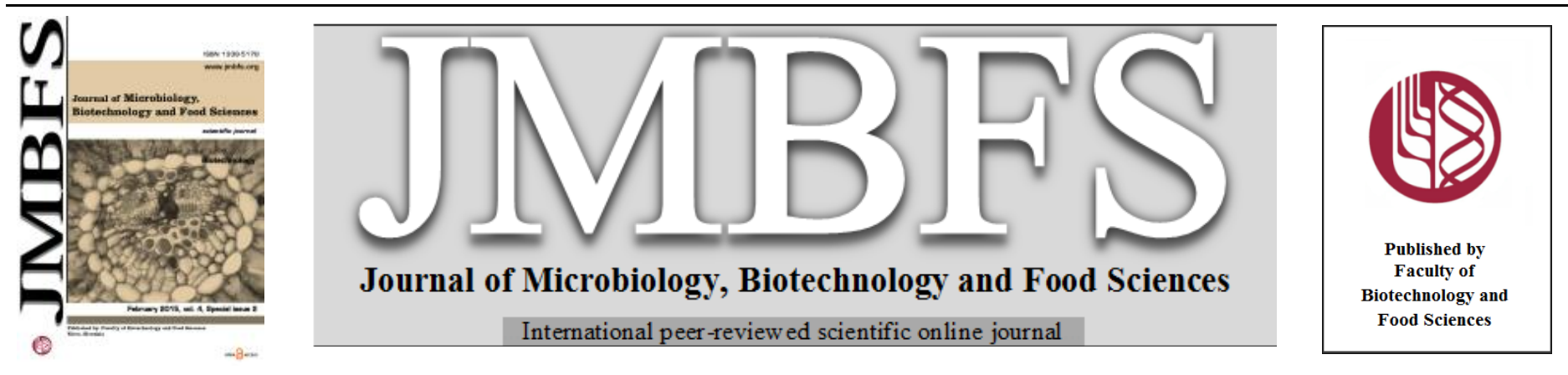

\title{
ESTRUS INDUCTION IN THE SOWS WITH ECG INJECTION 24h AFTER WEANING WITHIN WARM AND COOL SEASON
}

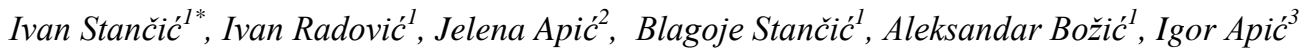 \\ Address(es): DVM, Ivan Stančić, PhD, Assistant Professor., \\ ${ }^{1}$ University of Novi Sad, Faculty of Agriculture, Departments of Vet. Medicine and Animal Prod., Trg D. Obradovića 8, 21000 Novi Sad, Serbia. \\ ${ }^{2}$ Scientific Veterinary Institute "Novi Sad", Rumenački put 20, 21000 Novi Sad, Serbia. \\ ${ }^{3}$ Veterinary Institute, ,Subotica“, Beogradski put 123, 24000 Subotica, Serbia.
}

*Corresponding author: dr.ivan.stancic@gmail.com

doi: 10.15414/jmbfs.2015.4.special2.105-107

ARTICLE INFO

Received 12.11.2014

Revised 24. 12. 2014

Accepted 8. 1. 2015

Published 2. 2. 2015

$\underline{\text { Regular article }}$

open $O$ access

\begin{abstract}
Numerous studies show significantly reduced sows fertility in the warm period of the year. The aim of this study was to investigate the effect of sows treatment with eCG preparation, 24h after weaning, on the estrous reaction level in the cool and warm season of the year. A significantly $(\mathrm{p}<0.01)$ higher number of sows, treated in warm season with single eCG injection of $1,000 \mathrm{IU}$ (primiparous) or $1,500 \mathrm{IU}$ (older sows), manifested estrus within 7 days after weaning (83.7\%) in comparison with the sows which were not treated (63.9\%). In addition, the treatment with eCG results in a high level of estrus synchronization, both in the warmer and in the cooler season of the year. Namely, on day 4 and day 5 after weaning, estrus was detected in $81 \%$ of eCG treated sows within the cooler season, and in $78 \%$ of sows treated in the warmer season. These values were significantly $(\mathrm{p}<0.01)$ lower in the control (untreated) sows $(41.1 \%$ in the cooler, vs. $33.3 \%$ in the warmer season). The obtained results show that the treatment with placental gonadotropin can be an effective method of increasing sow fertility in the wormer season of the year.
\end{abstract}

Keywords: Estrus, induction, eCG, weaning, season, sow

\section{INTRODUCTION}

The herd reproductive efficiency in the industrial pig production is measured by the number of weaned piglets per sow per year. This value, however, can vary greatly due to the influence of many genetic and paragenetic factors. However, as the heritability for the average number of weaned piglets per litter was about $10 \%$, the phenotypic value of this parameter is significantly affected by many paragenetic factors (See, 2002). The main parameters of fertility such as the weaning-to-estrus interval, farrowing rate, embryonic or fetal survival rate, live born piglets per litter and the piglets survival rate during the lactation, are the most important factors which influence the number of weaned piglets per sow per year (Nielsen, 1981a; Tomes et al., 1982; Stančić, 1994).

The value of these fertility parameters can be modified by the influence of numerous factors of infective and non-infective etiology (Vanroose et al., 2000; Stančić et al., 2011). Mostly frequent non-infective causes of reduced fertility are: nutrition, housing, insemination technology, body condition, treatment with placental gonadotropin (eCG and hCG) and general health status of sows (Stančić, 2005, Stančić et al., 2010; Stančić et al. , 2011). Under modern production conditions, a phenomenon known as "seasonal infertility of pigs" is the most important factor in reducing sow fertility parameters. Moreover, during the last 20 years, significantly lower values of the sow fertility parameters have been recorded in the warmer part of the year (Almond, 1992). The studies in Eastern Europe have shown a significant prolongation of weaning-to-estrus interval, reducing farrowing rate and litter size, as well as an increase in the number of regular and irregular return (rebreeding) rate, during the warmer periods of the year (Almond and Bilkei, 2005). It has been shown that treatment with placental gonadotropins (eCG and hCG), immediately after weaning, can successfully synchronize estrus and reduce the weaning-to-estrus interval (Almond and Bilkei, 2005; Taker et al., 2008; Stančić et al., 2010).

Therefore, the aim of this study was to investigate whether it is possible to reduce the weaning-to-estrus interval and increase the farrowing rate in sows after the treatment with placental gonadotropin eCG, within the warmer period of the year, in the serbian intensive pig production conditions.

\section{MATERIAL AND METHODS}

Farm and sows managing. The experiment was conducted on one large pig farm unit in the AP Vojvodina (Serbia), in a one year period. The farm capacity was about 5,000 of breeding sows (purebreds Large White, German Landrace, Dutch Landrace, Duroc and Hampshire, as well as their crosses F1 and F2 generations). The pregnant sows were kept for about 30 days in individual boxes, and later, up to about 7 days before farrowing, in the group boxes with outlets. During lactation, lasting about 30 days, the sows were housed in individual pens. After weaning, up to successful insemination, sows were kept in the group boxes with outlets. Sow feeding was adequate. The estrus detection was performed in the presence of a teaser boar once a day. The artificial insemination was performed by liquid diluted semen, with $100 \mathrm{ml}$ volume doses, containing about $4 \times 10^{9}$ progressively motile sperm, few hours after estrus detection, and about 24 hours later. The control of rebreeding was performed in the facilities for inseminated (pregnant) sows, starting about 14 days after insemination.

The hormonal treatment was carried out about 24 hours after weaning litters. Placental gonadotropin preparation eCG (equine chorionic gonadotropin), formerly known as PMSG ("Sugonal" Veterinary Institute Subotica, Serbia), was used. Each sow was treated with a single intramuscular injection of 1,000 IU eCG (first farrowing) or 1,500 IU eCG (older sows), during the warmer (May September) or cooler (October - April) seasons of the year. The estrus detection was performed in the presence of a teaser boar once a day, starting about $24 \mathrm{~h}$ after eCG injection.

Statistical analysis. The data were analyzed by the software package "Statistics 12 ". Mean, standard deviation, minimum and maximum values of the studied traits were determined. T-test were used for testing the significance of differences between the means of investigated values.

\section{RESULTS AND DISCUSSION}

Approximately 24 hours after weaning, the sows were treated with a single intramuscular injection of eCG (1,000 IU first parity sows, and1,500 IU older sows), in the cooler and warmer season of the year. The objective was to determine whether the treatment with gonadotropin preparation may increase the degree of sow estrus reaction, within the first 7 days after weaning, during the warmer season of the year. It has been shown that a significantly $(\mathrm{p}<0.01)$ larger 
number of the total sows treated with eCG (83.7\%) manifested estrus within the first 7 days after weaning in comparison with the control (non-treated) sows $(63.9 \%)$. A significant $(\mathrm{p}<0.01)$ increase in estrus reaction, within the first 7 days after weaning, in the eCG-treated sows, compared to the control sows, during the warm period of the year, were found in the first parity sows (76.5\% vs. $49.7 \%)$ as well as in the older sows $(85.2 \%$ vs. $67 \%)$ (Table 1$)$.

Table 1 Sows estrual reaction within first 7 days after weaning (average \pm SD)

\begin{tabular}{|c|c|c|c|c|c|c|}
\hline \multirow{3}{*}{ Parity } & & & \multicolumn{4}{|l|}{ Treatment } \\
\hline & & & \multicolumn{2}{|c|}{$\mathrm{eCG}$} & \multicolumn{2}{|c|}{ Control } \\
\hline & & & Cool season & Warm season & Cool season & Warm season \\
\hline \multirow{3}{*}{1.} & Treated & & 132 & 98 & 264 & 191 \\
\hline & \multirow{2}{*}{ In estrus } & $\mathrm{n}$ & 107 & 75 & 175 & 95 \\
\hline & & $\%$ & $81,1 \pm 3.68^{\mathrm{A}}$ & $76,5 \pm 3 \cdot 21^{\mathrm{A}}$ & $66,3 \pm 2.08^{\mathrm{B}}$ & $49,7 \pm 1.12^{\mathrm{C}}$ \\
\hline \multirow{3}{*}{$\geq 2$} & Treated & & 684 & 492 & 1211 & 869 \\
\hline & \multirow{2}{*}{ In estrus } & $\mathrm{n}$ & 618 & 419 & 1056 & 582 \\
\hline & & $\%$ & $90,3 \pm 4.23^{\mathrm{A}}$ & $85,2 \pm 3.87^{\mathrm{A}}$ & $87,2 \pm 3.43^{\mathrm{A}}$ & $67,0 \pm 2.56^{\mathrm{B}}$ \\
\hline \multirow{3}{*}{ Total } & Treated & & 816 & 590 & 1475 & 1060 \\
\hline & \multirow{2}{*}{ In estrus } & $\mathrm{n}$ & 725 & 494 & 1231 & 677 \\
\hline & & $\%$ & $88,8 \pm 2.87^{\mathrm{A}}$ & $83,7 \pm 3.11^{\mathrm{A}}$ & $83,4 \pm 3.25^{\mathrm{A}}$ & $63,9 \pm 1.93^{\mathrm{B}}$ \\
\hline
\end{tabular}

Values with different superscripts, within same row, significant $\operatorname{differ}\left({ }^{\mathrm{A}, \mathrm{B}} \mathrm{p}<0,01 ;{ }^{\mathrm{a}, \mathrm{b}} \mathrm{p}<0,05\right)$.

It is important to point out that the number of estrus sows, treated with eCG in the warmer, compared to the cooler season, was reduced by only $5 \%(\mathrm{p}>0.05)$ both in the primiparous sows $(76.5 \%$ vs. $81.1 \%)$ and in the older sows $(85.2 \mathrm{vs}$ $90.3 \%)$. However, this value in the control sows, significantly $(\mathrm{p}<0.01)$ decreased in the warmer season by $16.6 \%$ in the primiparous sows $(49.7 \%$ vs. $66.3 \%)$ and by $20.2 \%$ in the older sows $(67 \%$ vs. $87.2 \%)$ (Table 1). Furthermore, the treatment with eCG results in high level of postweaning estrus synchronization, both in the warmer and cooler season of the year. Namely, on day 4 and day 5 after weaning, estrus was induced in $78 \%$ of sows treated in the warm, and in $81 \%$ of sows treated in the cool season of the year (Figure 1). However, in the same weaning-to-estrus interval of untreated (control) sows, estrus was detected in only $41.1 \%$ of sows in the cool, and in $33.3 \%$ of sows in the warm season of the year (Figure 2).

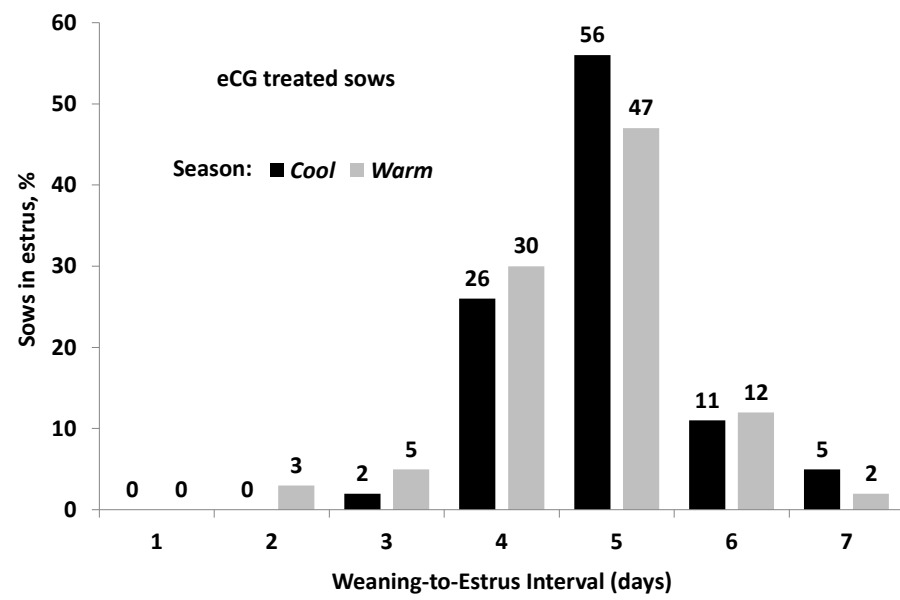

Figure 1 Distribution of weaning-to-estrus interval in eCG treated sows

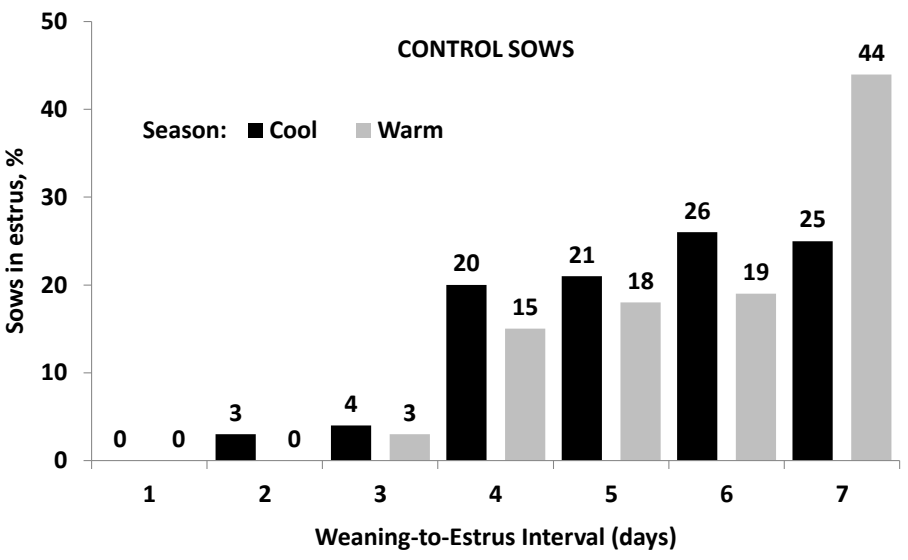

Figure 2 Distribution of weaning-to-estrus interval in control sows
In a good reproductive performance herds, over $85 \%$ of sows manifest the first estrus within 7 days after weaning (Tubbs, 1990; See, 2000). The intervals longer than this are considered to be extended (abnormal) and they are an indication of disturbed activity of re-establishing postlactation ovarian activity, as well as of the possibility of lower reproductive efficiency of such sows in the following reproductive cycle (Napel et al., 1998). Seasonal infertility is wellknown phenomenon in the pig reproduction. It is manifested with lower values of the basic parameters of sow fertility during the summer months (Stančić et al., 2011). Some of these parameters are: increased occurrence of postweaning anestrous, extended weaning-to-estrus interval, lower values of conception rate, increased number of rebreeding, abortions and pseudopregnancy, as well as the lowered number of vital live-born pigs (Rozeboom et al., 2000; Almond and Bilkei, 2005). This is associated with the negative effects of high ambient temperature, on the hormonal mechanisms (release the pituitary FSH and LH) that re-establish postweaning estrus response, as well as on the establishmen and/or maintenance of pregnancy (lower conception rate and increase embryonal or foetal mortality) (Britt et al., 1983; Xue et al., 1994; Stančić, 1994; Prunier and Quesnel, 2000; Bassett et al., 2001; Peters and Pitt, 2003; Stančić et al., 2011). Delayed of re-establishing postlactation ovarian activity (follicular growth, ovulation and estrus manifestation) is, most frequently, the consequence of prolonged daily photoperiod and the increase of ambiental temperature during warm summer months (Peltoniemi et al., 1999). It appears that the extended weaning-to-estrus interval (WEI), during the warm season, is the consequence of reduced capability of hypothalamus to re-establish normal pulsatile secretion of Gn-RH. This inhibits the release of hypophyseal gonadotropins (FSH and LH), which results in delaying of the first post-lactation ovulation occurrence and manifestation of estrus (Prunier et al., 1996). The effect of the increased ambiental temperature on the WEI increasing, can be explained indirectly. Namely, it is well-known that the appetite of sows is significantly lowered during the summer months (Aherne and Kirkwood, 1985), and that reduced intake of energy in the organism reduces or inhibits secretion of LH (Prunier et al., 1996) This results in delayed follicles maturing and ovulation after weaning and, consequently, increase WEI duration (Kirkwood, 2009). On the other hand, the extended daily photoperiod has direct effects, through the influence of the reduced pineal melatonin secretion on the inhibition of hypothalamus Gn-RH secretion and, consequently, inhibitiom of hypophyseal gonadotropins releasing (Tast, 2002). Treatment of weaned sows with gonadotropins (eCG or hCG, or eCG+hCG) result in high level of postweaning estrus synchronization, as well as in significant decreasing of weaning-to-estrus duration (Bracken et al., 2006; Franek et al., 2008; Kirkwood, 2009; Stančić et al., 2010) and can prevent seasonal infertility in the sows (Taker et al., 2008; Stančić et al., 2010).

The results of our study show that, after a single eCG injection $24 \mathrm{~h}$ after weaning, during the warm period of the year, a significantly $(\mathrm{p}<0.01)$ higher number of sows manifested estrus $(83.7 \%)$ within 7 days after weaning, compared to sows which were not treated $(63.9 \%)$. Similar results were obtained by other authors (Almond and Bilkei 2005; Bracken et al., 2006; Tuker et al., 2008; Stančić et al., 2010). These results clearly demonstrate that the treatment with placental gonadotropin (eCG) about $24 \mathrm{~h}$ after weaning, can be an effective method of increasing and synchronizing the sow postweaning estrus reactions, and significantlly decreasing weaning-to-estrus interval in the wormer season. Therefore, it can contribute to the reduction of sow infertility level during the warm summer months. 


\section{CONCLUSION}

Based on the obtained results, it can be concluded that the treatment of sows with placental gonadotropin eCG, 24 hours after weaning, can significantly increase the number of sows in estrus within the first 7 days after weaning, during the warm season of the year.

These results demonstrate that postweaning gonadotropins treatment can contribute to the reduction of the negative influence of warm season on sow fertility in the intensive pig production herds

\section{REFERENCES}

AHERNE, F.X. and KIRKWOOD, N.R. 1985. Nutrition and sow prolificacy. $J$. Reprod. Fert., 33, 169-178.

ALMOND, P.K. and BILKEI, G. 2005. Seasonal infertility in large pig production units in a Eastern-Europian climate. Australian Veterinary Journal, 83(6)344-346.

ALMOND, W.G. 1992. Seasonal infertility in female pigs. Healthy Hogs, 1, 1-5. BASSETT, J.M., BRAY, C.J., SHARPE, C.E. 2001. Reproductive seasonality in domestic sows kept outdoors without boars. Reproduction, 121, 613-629.

BRACKEN, J.C., SEAMAN-BRIDGES, J. S., SAFRANSKI, T. J., LUCY, M. C. 2006. Ovarian follicular development, estrus, and ovulation in seasonally anestrous sows treated seven days post weaning with equine and human chorionic gonadotropins. J. Swine Health Prod., 14(4)207-209.

BRITT, J.H., SZAREK, V.E., LEVIS, D .G. 1983. Characterization of summer infertility of sows in large confinement unit. Theriogenology, 20, 133-140.

FRANEK, P.S., BILKEI, G., KOVAČ, G. 2008. Effect of gonadotropins during hot summer season given at different times after weaning an selected reproductive indicators of the sows. Acta Vet. Brno, 77, 193-198.

KIRKWOOD, N.R. 2009. Managing seasonal infertility in sows. Vets.Web., 11, $1-12$.

NAPEL, J., MEUWISSEN, T.H.E., JOHNSON, K.R., BARASCAMP, E.W

1998. Genetics of the Interval from Weaning to Etsrus in First-Litter Sows Correlated Responses. J. Anim. Sci., 76, 937-947.

NIELSEN, H.E. 1981a. Sow productivity. Proceding of work of Alberta Pork Seminar. University of Alberta, pp. 1-17.

PELTONIEMI, O.A., HEINONEN, M., LEPPÄVUORI, A., LOVE, R.J. 1999. Seasonal effects on reproduction in the domestic sow in Finland: a herd record study. Acta Vet. Scand., 40(2)133-44.

PETERS, A.R. and PITT, R.L. 2003. Seasonainl fertility in pigs in the east of England. Pig Journal, 52, 13-27.

PRUNIER, A. and QUESNEL, H. 2000. Influence of the nutritional status on ovarian development in female pigs. Anim. Reprod. Sci., 4, 185-197.

PRUNIER, A., QUESNEL, H., MESSIAS, M., KERMABON, Y.A. 1996 Environmental and seasonal influence on the return-to-estrus after weaning in primiparous sows: a review. Livestock Prod. Sci., 45, 103-110.

SEE, T. 2000. Good estrus detectin is a key to successful insemination. Swine News, 23(2)1-2.

SEE, T. 2002. Genetic selection for AI traits. Swine News, 25(6)1-6.

STANČIĆ JELENA, GAGRČIN, M., APIĆ, I., DRAGIN, S. 2010. Estrus reaction in sows treated with PMSG after weaning in the cold and warm period of the year. Proceding of work of 21. Symp. "Animal husbandry, veterinary medicine and economics in rural development and the healthy and food safety production «, with the international participation, Divčibare (Serbia), 20. - 27. Jun, 2010. P. 71.

STANČIĆ, B., BOŽIĆ, A., STANČIĆ, I., RADOVIĆ, I., DRAGIN, S. 2011 Sow seasonal infertility. Contemporary Agriculture, 60(1-2)195-203.

STANČIĆ, B. 1994. Faktori koji utiče na neke parametre reproduktivne performanse krmača. Vet. glasnik, 48(5-6)345-472.

STANČIĆ, B. 2005. Reproduction of Swine (monography). University of Novi Sad, Faculty of Agriculture.

STANČIĆ, I., STANČIĆ, JELENA, APIĆ, I. 2011. Infective etiology of sows reproductive disorders. Proceding of the work of XVI Advising on Biotechnology, Čačak (Serbia), 4.-5. Mart, 2011. Pp. 255-260.

TAKER, M.Y.C., BILKEI, G., KOVAČ, G. 2008. Gonadotropin treatment prevents seasonal infertility in the sow. Folia veterinaria, 5(2)106-108.

TAST, A. 2002. Endocrinological basis of seasonal infertility in pigs. $P h D$ Thesis, Faculty of Veterinary Medicine, Finland, Helsinki.

TOMES, J.G. and NIELSEN, H.E. 1982. Factors affecting reproductive efficiency of the breeding herd. In: Control of Pig Reproduction (D.J.A Cole and G.R. Foxcroft, eds.). Butterworths, London, pp.527-540.

TUBBS, C.R. 1990. Factors That Influence the Weaning-to-Estrus Interval in Sows. Comp. Cont. Edication for the Preact. Vet., 12(1)105-115.

VANROOSE, G., KRUIFT, DE A., SOON VAN A. 2000. Embryonic mortality and embryo - pathogen interactions. Anim. Reprod. Sci., 60-61, 131-143.

XUE, J.L., DIAL, G.D., MARSH, W.E., DAVIES, P.R. 1994. Multiple manifestations of season on reproductive performance of commercial swine JAVMA., 204, 1486-1489. 